Reynolds, E. L. (1944). Child Developm. 15, I 8 I.

Reynolds, E. L. (1950). Monogr. Soc. Res. Child Developm. 15, no. 2.

Siri, W. E. (1956a). Body Composition from Fluid Spaces and Density: Analysis of Methods. MS no. UCRL 3349: Donner Laboratory, University of California.

Siri, W. E. (1956b). Rev. sci. Instrum. 27, 729.

Stuart, H. C., Hill, P. \& Shaw, C. (1940). Monogr. Soc. Res. Child Developm. 5, no. 3.

Tanner, J. M. (1955). Growth at Adolescence. Oxford: Blackwell's Scientific Publications.

Tanner, J. M. \& Whitehouse, R. H. (1955a). Amer. F. phys. Anthrop. N.S. 13, 743.

Tanner, J. M. \& Whitehouse, R. H. (1955b). Nature, Lond., 176, 1 I 80.

Tanner, J. M., Whitehouse, R. H. \& Powell, J. H. (1958). Lancet, ii, 779.

Welham, W. C. \& Behnke, A. R. Jr. (1942). F. Amer. med. Ass. I18, 498.

\title{
Some aspects of metabolism of the obese
}

By G. L. S. Pawan, Department of Medicine, Middlesex Hospital, London, W.

For many generations obesity has been a subject of major interest in countries with a high standard of living and readily available food supplies, and in recent years a voluminous literature on this condition has accumulated in both the lay and medical press. Much work has been carried out on metabolism in the obese; there has been even more speculation, but the problem still remains a vexed one.

In this paper, only certain aspects of metabolism in the obese human being will be presented. The many important contributions of various workers have been reviewed by others (Rynearson \& Gastineau, 1949; Newburgh, 1950; Evans, 1952; McCance, I953a, $b$; Mayer, I953, I955a,b, 1957; Bernhardt, I955; Berryman, I955; Vague \& Benoit, I956).

More than 50 years ago, von Noorden (1907) suggested a classification of obesity into (a) an exogenous or simple type caused by manifest overeating, and (b) an endogenous type produced by, or associated with, various metabolic abnormalities. The work of Newburgh and his collaborators (Newburgh, 1950) appeared to refute the existence of this latter type, and as a result attention has largely been focused on the factors regulating appetite and food intake; the usual treatment has been to reduce total calorie intake, by devious means, below the theoretical calorie requirement of the individual.

In recent years, the experiments of Mayer and his colleagues (Mayer, I957) in particular have shown the definite existence of 'metabolic' abnormalities in certain types of obesity in animals: these are distinct from 'regulatory' types of obesity in which mainly factors controlling food intake are deranged. In man, despite the belief of Newburgh (1950) that metabolism in the obese subject differs in no respect from that in the non-obese, it is felt by some that the question is far from settled and that much is yet to be learned about obesity from careful metabolic studies on man.

In the mid-nineteenth century, William Banting (1864) observed on himself that weight was lost most readily on a diet low in carbohydrate. More recently, Pennington (195 I, I954) has attributed obesity in man to a defect in carbohydrate metabolism and has reported successful treatment of the condition with an unrestricted calorie intake from diets high in fat and low in carbohydrate. However, the 
effectiveness of this type of diet has been questioned by Werner (1955), who attributes the weight changes produced by it to loss of water and of salt rather than to increased reduction of adipose tissue.

It was observed (Kekwick \& Pawan, 1953, 1956, 1957) that, in obese patients on $1000 \mathrm{kcal}$ diets with constant intakes of water and salt, weight loss was greatest when fat provided most of the calories and least when the carbohydrate content was high

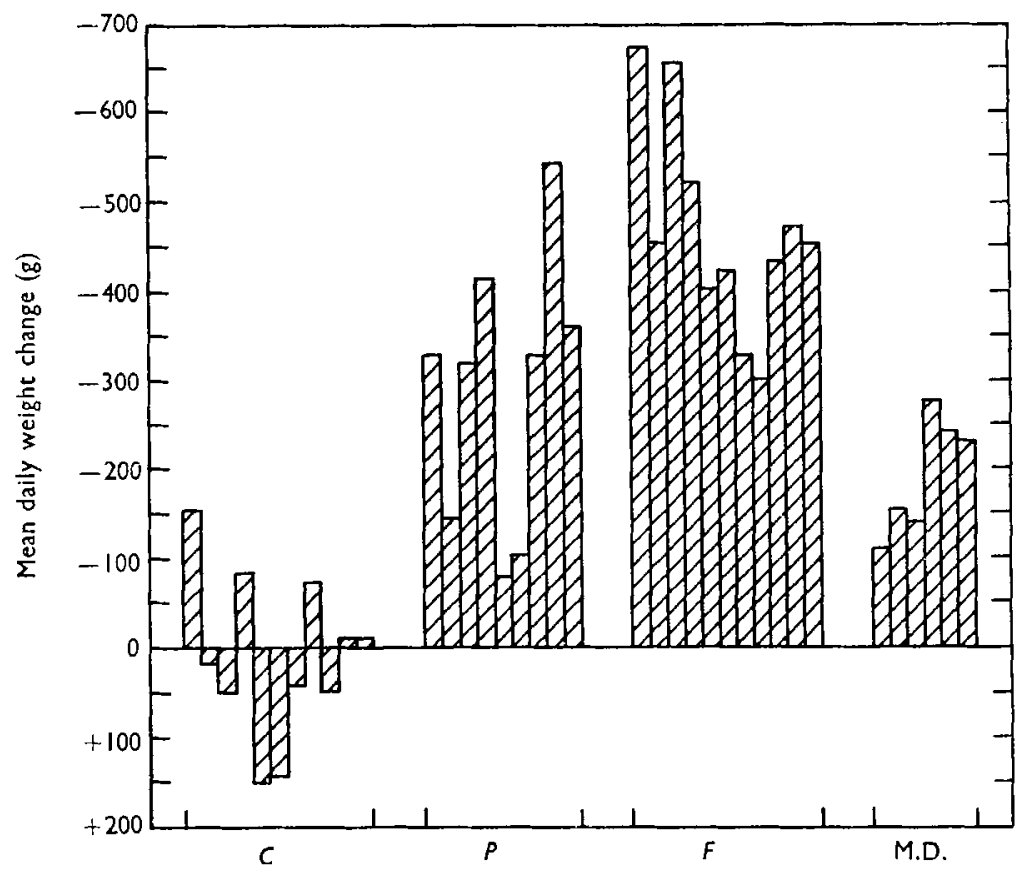

Fig. I. Effect on mean daily weight change of obese people (mean values for periods of $5-9$ days) of variation in the proportion of carbohydrate, protein or fat in a $1000 \mathrm{kcal}$ diet. $C, 90 \%$ of the calories as carbohydrate; $P, 90 \%$ of the calories as protein; $F, 90 \%$ of the calories as fat; M.D., mixed diet.

(Fig. I). These differences in loss of body-weight did not appear to be solely the result of either variations in body hydration or of defective food absorption. On these diets no significant changes in B.M.R. could be detected (Table I), but the rate of insensible weight loss was greatest on the high-fat and least on the high-carbohydrate diet (Figs. 2 and 3 ). It was suggested that energy metabolism, undetected by measurements of B.M.R., may have been variously affected as a result of the qualitative differences in the diets; in addition, mobilization and katabolism of body fat may have been stimulated by the high-fat diet, as judged by the urinary excretion of a fat-mobilizing substance. This fat-mobilizing material (Chalmers, Kekwick, Pawan \& Smith, 1958) could be extracted from the urine of fasting normal subjects and of obese patients losing weight on rooo kcal high-fat diets. The material was not present to any significant degree (by the criteria employed) in the urine of the same normal subjects when eating an ordinary diet, or in the urine of the obese patients on $1000 \mathrm{kcal}$ diets containing $90 \%$ of the calories in the form of carbohydrate (Table 2 ). 
Table I. Changes in B.M.R. (Robertson $\xi^{\circ}$ Reid (I952) standards) in patients during periods on $1000 \mathrm{kcal}$ diets with different proportions of fat, protein and carbohydrate

(Results are expressed as percentages of the standard normal values. Each figure represents the difference between the B.M.R. reading at the beginning and at the end of the period for a single patient)

\begin{tabular}{|c|c|c|}
\hline $\begin{array}{c}90 \% \text { of calories } \\
\text { as fat }\end{array}$ & $\begin{array}{l}90 \% \text { of calories } \\
\text { as protein }\end{array}$ & $\begin{array}{l}90 \% \text { of calories } \\
\text { as carbohydrate }\end{array}$ \\
\hline 0 & -2 & +3 \\
\hline-3 & +3 & 0 \\
\hline-3 & +4 & +2 \\
\hline+4 & -I & 0 \\
\hline- - I I & +2 & +5 \\
\hline$+I$ & - I I & +5 \\
\hline-2 & -9 & +15 \\
\hline-2 & +6 & $-\mathbf{I}$ \\
\hline+2 & & -5 \\
\hline+5 & & +2 \\
\hline
\end{tabular}

This fat-mobilizing material was shown to produce, when injected into normal mice: (I) an increase in the total fat content of the liver, presumably by mobilization of lipid from fat depots, (2) an apparent increase in katabolism of body fat, (3) an increase in the lipids and 'ketone bodies' of the blood, and (4) a reduction of bodyweight and body fat without any appreciable effect on food intake.

During short-term experiments (Kekwick \& Pawan, 1953, I956, I957) obese subjects were able to conserve body protein stores, as determined by nitrogen

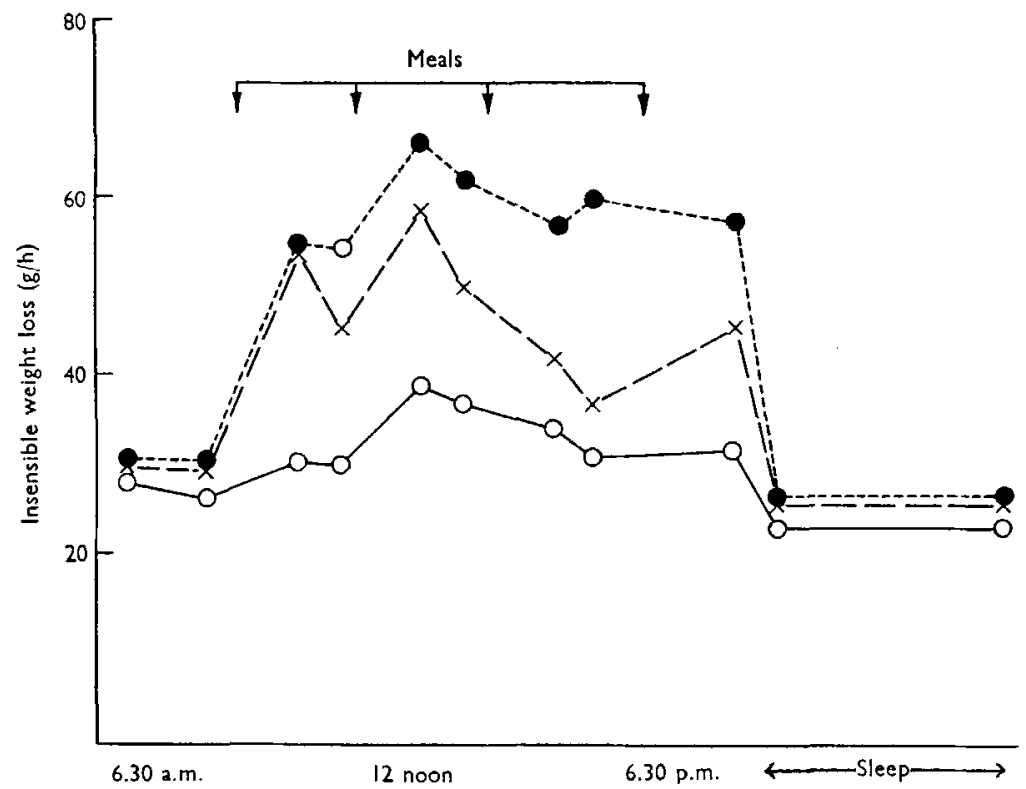

Fig. 2. Relation of insensible weight loss to change of diet in three obese subjects. Each point is the mean of nine readings...--0 , high-fat diet; $\times----\times$, high-protein diet; $0-$ high-carbohydrate diet. All diets provided $1000 \mathrm{kcal}, 90 \%$ from fat, protein, and carbohydrate, respectively. 


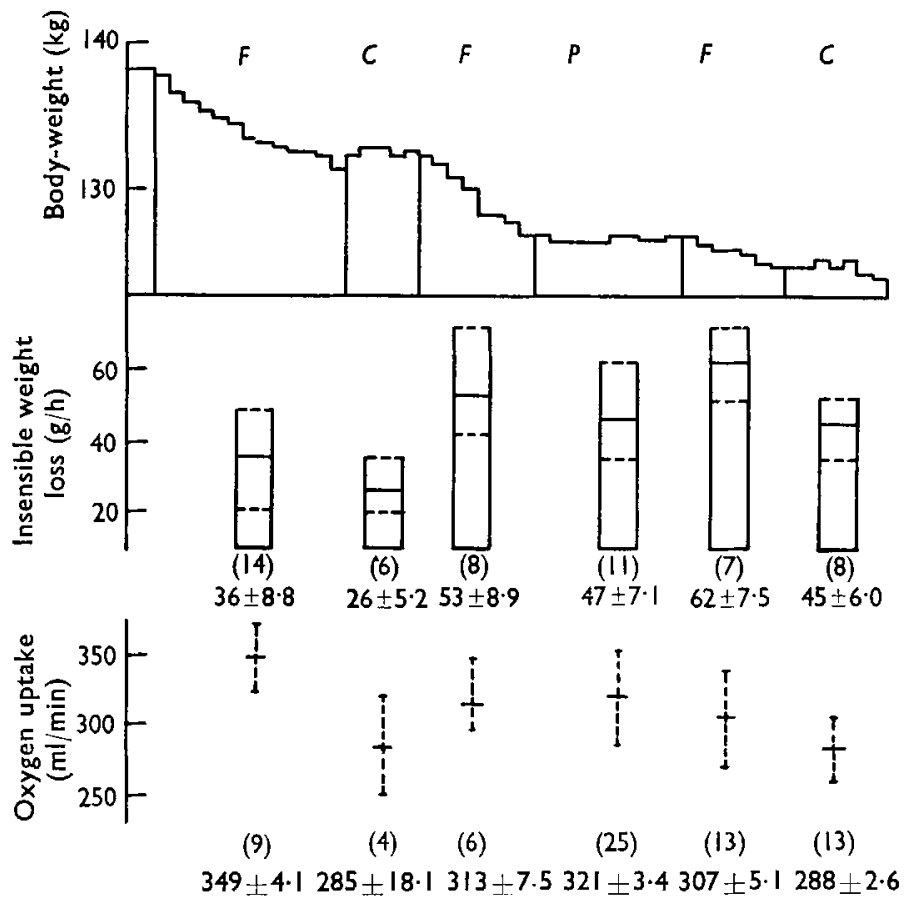

Fig. 3. Change in body-weight, rate of insensible weight loss and oxygen uptake in an obese subject on $1000 \mathrm{kcal}$ diets with different proportions of fat, carbohydrate and protein. $F, 90 \%$ of the calories as fat; $C, 90 \%$ of the calories as carbohydrate; $P, 90 \%$ of the calories as protein. The figures in parentheses show the numbers of measurements and those below them the mean values with their standard errors.

Table 2. Fat-mobilizing activity of extracts of urine from three obese female subjects on 1000 kcal diets containing $90 \%$ of the calories as carbohydrate, fat or protein.

(The activity was detected by chromatography and assayed by the effect of the extracts on the fat content of mouse liver (see Chalmers et al. 1958))

\begin{tabular}{clc}
$\begin{array}{c}\text { Patient } \\
\text { no. }\end{array}$ & \multicolumn{1}{c}{$\begin{array}{c}\text { Diet } \\
\text { I }\end{array}$} & $\begin{array}{c}\text { High-carbohydrate } \\
\text { change } \\
(\mathrm{kg} / \text { week })\end{array}$ \\
& High-fat & -0.8 \\
2 & High-carbohydrate & -0.4 \\
& High-fat & -2.5 \\
& High-protein & -0.5 \\
3 & High-fat & -2.3 \\
& High-protein & -0.8 \\
& High carbohydrate & +0.1
\end{tabular}

$\begin{array}{cc}\text { Increase } & \\ \text { in mouse } & \\ \text { liver fat } & \text { Chromatographic } \\ (\%) & \text { evidence } \\ 7 & \circ \\ 47 & + \\ 2 & 0 \\ 73 & + \\ 39 & + \\ 65 & + \\ 50 & + \\ \text { 13 } & 0\end{array}$

balance, more effectively than non-obese subjects when given low-protein, calorierestricted diets (Fig. 4; Table 3). Similar findings had already been reported by Keeton \& Dickson (I933) and by Strang, McClugage \& Evans (193 I).

Of particular interest is the effect of a $1000 \mathrm{kcal}$ diet providing $90 \%$ of the calories as fat on the metabolic pattern of obese patients (Fig. 5 ; Table 3 ). Non-obese subjects, after a few days on this diet, develop marked ketonaemia, ketonuria, hypoglycaemia and negative nitrogen balance; the obese exhibit little or no ketosis, maintain 


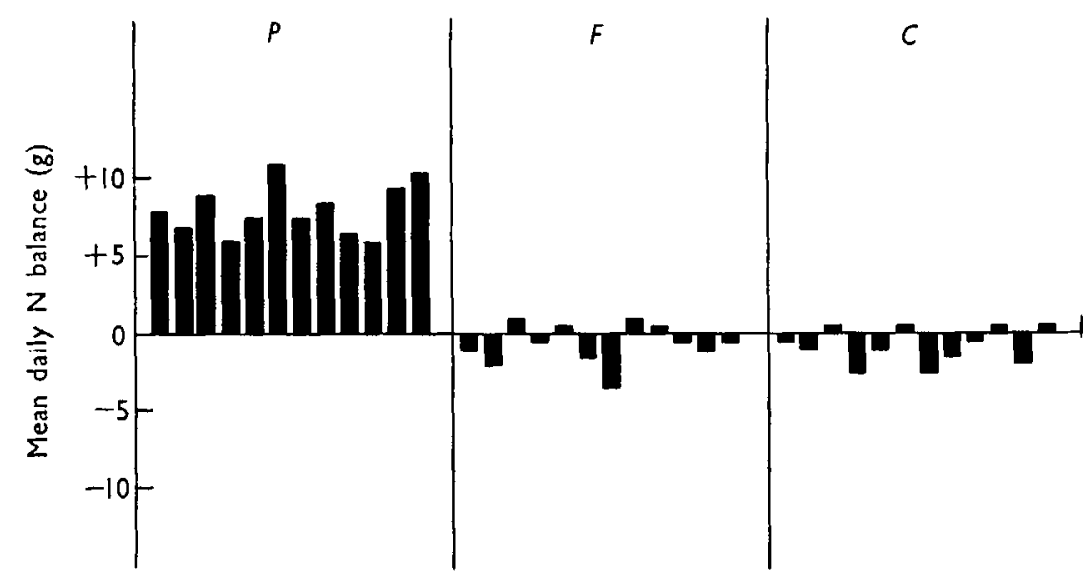

Fig. 4. Nitrogen balances of twelve obese subjects during $5^{-1} 4$ days on $1000 \mathrm{kcal}$ diets with different proportions of protein, fat and carbohydrate. $P, 90 \%$ of the calories as protein; $F, 90 \%$ of the calories as fat; $C, 90 \%$ of the calories as carbohydrate.
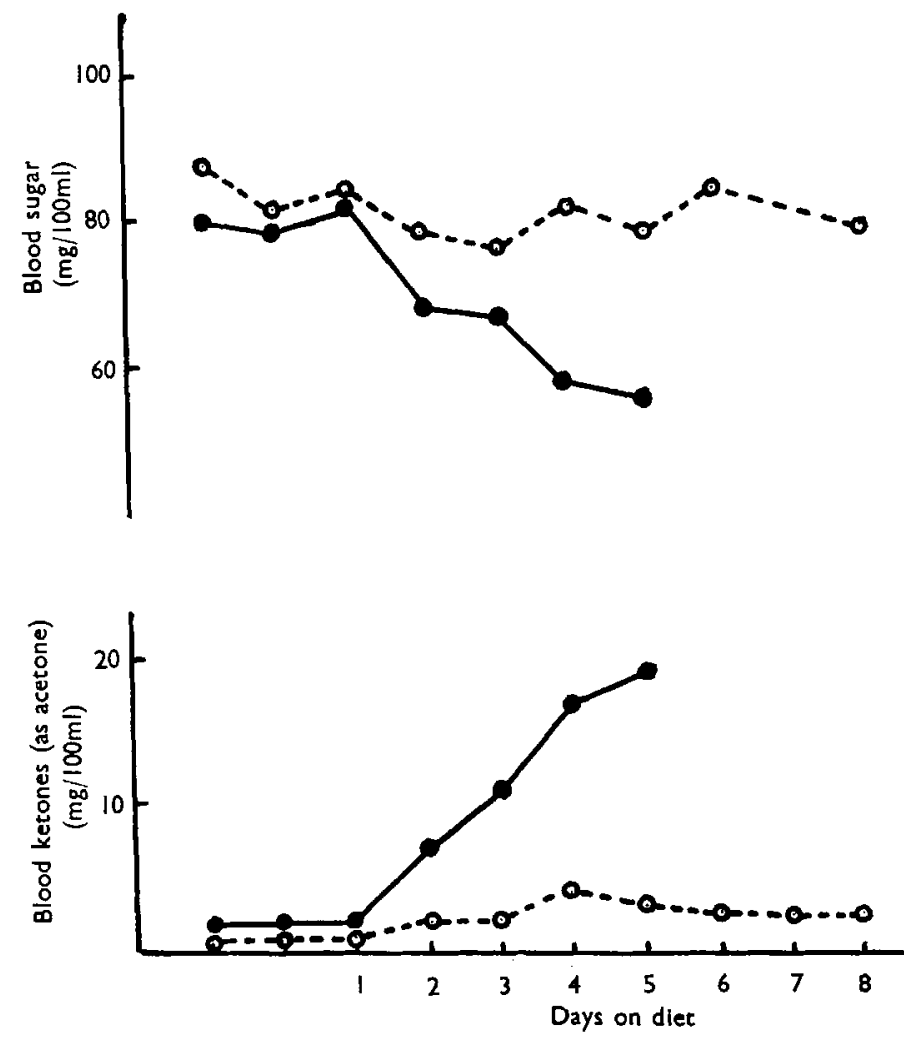

Fig. 5. Effect of a $1000 \mathrm{kcal}$ diet, containing $90 \%$ of the calories in the form of fat, on the blood-sugar and blood-ketone levels of an obese and of a non-obese subject. The diet supplied about roo $\mathrm{g}$ fat, $\mathrm{I} 2 \mathrm{~g}$ carbohydrate and $\mathrm{r} 6 \mathrm{~g}$ protein daily. $\mathrm{O}-\mathrm{O}$, obese subject; - - - 0 , normal subject.

blood-sugar and plasma-bicarbonate values within normal limits, show little protein loss (as judged by nitrogen balance), and appear to tolerate the diet without undue 
discomfort for at least a few weeks. These observations raise the question of the possible net conversion of fat into carbohydrate. Lyon, Dunlop \& Stewart (1932), from studies of the respiratory quotient of obese subjects, suggested that conversion of fat into carbohydrate may occur in them under certain conditions. This view was

Table 3. Effect of a $1000 \mathrm{kcal}$ diet containing $90 \%$ of the calories as fat on bodyweight, nitrogen balance, blood sugar, blood ketones and plasma bicarbonate in a non-obese and in an obese female subject

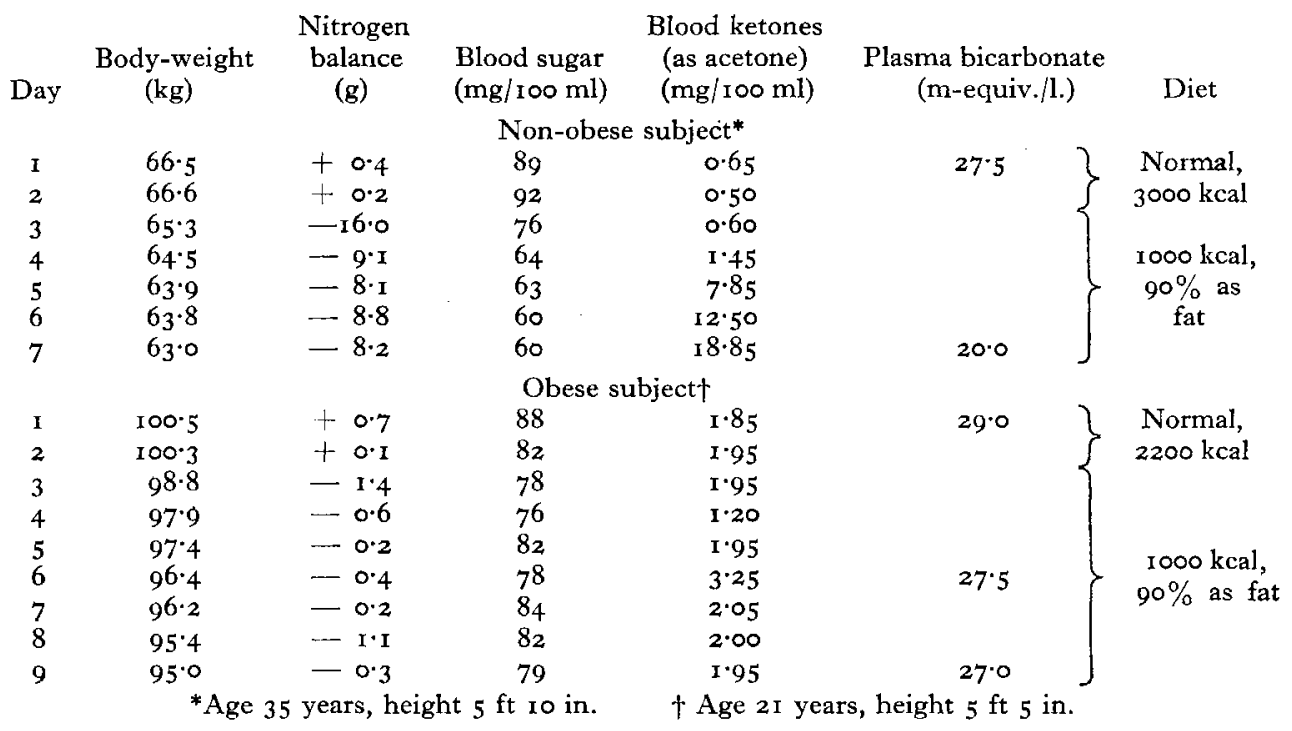

not generally accepted, and the subject of neoglucogenesis from fat has remained a controversial one (Weinman, Strisower \& Chaikoff, I957). The results just quoted would seem to indicate that fat is in fact being converted into carbohydrate, and that the obese are able to utilize fat for energy purposes more efficiently with respect to conservation of body protein and carbohydrate than the non-obese, which latter is said to occur in the normal rat on high-fat diets (Mayes, 1959). (Alternatively, only one of the above possibilities may operate in man.)

The main argument of those who oppose the concept of metabolic defects as a cause of obesity in man is based on the failure to demonstrate any clear-cut difference from the normal in energy utilization. Though it is certainly true that B.M.R. values, as usually estimated from measurements of oxygen uptake and R.Q., fall within the normal range in most obese persons, these measurements are based on many assumptions of doubtful validity in these persons. There is a paucity of accurate comparisons between the obese and non-obese of the daily oxygen uptake and carbondioxide output over prolonged periods. The classical assumption that heat production may be calculated from oxygen consumption and the R.Q. may be correct when complete oxidation of the protein, fat or carbohydrate in the metabolic mixture of the organism is taking place but, when incomplete oxidations and other metabolic changes are simultaneously occurring, the calorie equivalent of the oxygen consumed becomes a doubtful entity. 
The differences in the degree of reduction in weight seen in obese subjects on isocaloric reducing diets (Fig. I), if not due to shifts of body water or variations in food absorption, should entail proportional changes in oxygen uptake and carbondioxide output or physical activity in order to maintain energy balance. Though it may be so, it should not be overlooked that much is yet to be learned about the intracellular reactions that control coupled oxidative phosphorylation and formation of high-energy bonds (Portman \& Hegsted, I 957), as well as about the factors that regulate the conservation, liberation and utilization of this energy for physical work and other energy-requiring processes of the body. All these reactions may play a part in the relationship between apparent energy balance and oxygen utilization. Furthermore, with reference to the efficiency of food utilization, the reasons for the wide variations in energy expenditure between individuals doing identical tasks (Edholm, Fletcher, Widdowson \& McCance, I955; Passmore \& Durnin, 1955; Booyens \& McCance, I957; Booyens \& Keatinge, I957; Durnin \& Namyslowski, 1958) are still not clear, and the exact role of hormones, enzymes and genetic factors that may be implicated in obesity is even less understood.

The few points of difference between the obese and the non-obese subject which have been mentioned in this paper may well be the result rather than the cause of the obese state but, at least, they appear to warrant further investigation of this fascinating condition for possible differences in metabolism of even greater importance.

The experimental work, on which this paper is based, was carried out jointly with Professor Alan Kekwick to whom I would like to express thanks for stimulating advice and constant encouragement over many years.

\section{REFERENCES}

Banting W. (1864), Letter on Corpulence, Addressed to the Public. $4^{\text {th }}$ ed. New York: Mohun, Ebbs \& Hough.

Bernhardt, H. (1955). Fettleibigkeit. Stuttgart: Ferdinand Enke Verlag.

Berryman, G. H. (1955). F. Amer. diet. Ass. 31, 347.

Booyens, J. \& Keatinge, W. R. (1957). 7. Physiol. 138, 165.

Booyens, J. \& McCance, R. A. (1957). Lancet, 272, 225.

Chalmers, T. M., Kekwick, A., Pawan, G. L. S. \& Smith, I. (1958). Lancet, i, 866.

Durnin, J. V. G. A. \& Namyslowski, L. (1958). F. Physiol. 143, 573.

Edholm, O. G., Fletcher, J. G., Widdowson, E. M. \& McCance, R. A. (1955). Brit. F. Nutr. 9, 286.

Evans, F. A. (1952). In Diseases of Metabolism. Detailed Methods of Diagnosis and Treatment, 3 rd. ed. p. 601. [G. G. Duncan, editor.] London: Saunders.

Keeton, R. W. \& Dickson, D. (1933). Arch. intern. Med. 51, 890.

Kekwick, A. \& Pawan, G. L. S. (1953). Arch. Middlx Hosp. 3, 139.

Kekwick, A. \& Pawan, G. L. S. (1956). Lancet, 271, 155.

Kekwick, A. \& Pawan, G. L. S. (1957). Metabolism, 6, 447.

Lyon, D. M., Dunlop, D. M. \& Stewart, C. P. (1932). Biochem. F. 26, I 107.

McCance, R. A. (I953a), Lancet, 265, 685.

McCance, R. A. (1953b). Lancet, 265, 739 .

Mayer, J. (1953). Physiol. Rev. 33, 472.

Mayer, J. (1955a). Nutr. Abstr. Rev. 25, 597.

Mayer, J. (1955b). Nutr. Abstr. Rev. 25, 87 I.

Mayer, J. (1957). Metabolism, 6, 435.

Mayes, P. A. (1959). Biochem. \%. 71, 459 .

Newburgh, L. H. (1950). In Clinical Nutrition, p. 689. [N. Jolliffe, F. F. Tisdall and P. R. Cannon, editors.] New York: Paul B. Hoeber Inc.

$18(2) 6$ 
Passmore, R. \& Durnin, J. V. G. A. (1955). Physiol. Rev. 35, 80 I.

Pennington, A. W. (195I). Delaware St. Med. F. 23, 79.

Pennington, A. W. (1954). Amer. $\mathcal{F}$. dig. Dis. 22, 33.

Portman, O. W. \& Hegsted, D. M. (1957). Annu. Rev. Biochem. 26, 307.

Robertson, J. D. \& Reid, D. D. (1952). Lancet, 262, 940.

Rynearson, E. H. \& Gastineau, C. F. (r949). Obesity. Oxford: Blackwell.

Strang, J. M., McClugage, H. B. \& Evans, F. A. (I93 1). Amer. F. med. Sci. 181, 336.

Vague, J. \& Benoit, M. (1956). Marseille méd. 93, 541.

von Noorden, C. (1907). Metabolism and Practical Medicine. Chicago: W. T. Keener.

Weinman, E. O., Strisower, E. H. \& Chaikoff, I. L. (1957). Physiol. Rev. 37, $25^{2}$.

Werner, S. C. (1955). New Engl. F. Med. 252, 66r.

\section{The management of the obese patient}

\section{By Kathleen Rose, Dietetic Department, Royal Infirmary, Edinburgh}

Obesity is said to be the most common nutritional disturbance in this country. This statement is certainly true from the point of view of the dietitian, as obesity is one of the largest problems with which she is faced.

From the practical point of view the problem is clearly divided into the relatively simple one of the obese patient in hospital and the much larger and more difficult one of the obese patients who have to be treated in their own home surroundings.

In an attempt to assess this latter problem, the patients initially referred for weight reduction to the Dietetic Department of the Royal Infirmary of Edinburgh in the first 6 months of 1958 were studied. The total number of new patients of all types given dietetic instruction was $83 \mathrm{I} ; 407$ were non-diabetic obese persons requiring advice on weight reduction. Of these 407 patients $31(8 \%)$ were referred directly to the department by their own practitioners, $99(24 \%)$ were seen on discharge from the wards of the hospital and $287(68 \%)$ were sent as outpatients from other departments of the hospital.

The distribution of patients according to age and sex is shown in Fig. I. The ages ranged from 7 to 82 years, the largest group being in the middle range, $45^{-60}$. The number of females was slightly more than twice the number of males -287 females to 120 males. The distribution of the sexes was similar throughout the age groups with the exception of the group under ${ }_{5} 5$ in which there were more males than females. This variation may be due to the fact that the acquisition of 'puppy fat' in young girls does not usually result in their being referred for medical advice.

Ninety-nine (about $25 \%$ ) of the patients were referred for the treatment of uncomplicated obesity: the remaining $3 \mathrm{r} 8$ (about $75 \%$ ) suffered from some disability consequent upon their obesity or had to have their weight reduced in preparation for a surgical operation or because of orthopaedic, cardiac, circulatory or respiratory complications.

The percentage of excess weight was calculated from the tables of standard weight for height and age issued by the Metropolitan Life Insurance Company. The patients were weighed in indoor clothes with shoes. Thirty-five $(12 \%)$ of the patients 